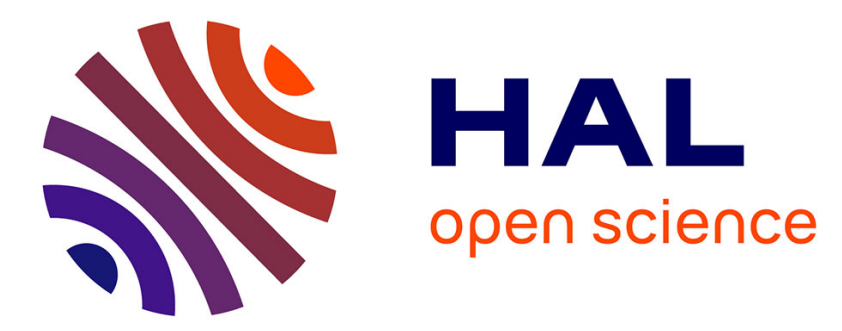

\title{
Iron-Catalysed Reductive Amination of Carbonyl Derivatives with $\omega$-Amino Fatty Acids to Access Cyclic Amines
}

Duo Wei, Chakkrit Netkaew, Victor Carre, Christophe Darcel

\section{- To cite this version:}

Duo Wei, Chakkrit Netkaew, Victor Carre, Christophe Darcel. Iron-Catalysed Reductive Amination of Carbonyl Derivatives with $\omega$-Amino Fatty Acids to Access Cyclic Amines. ChemSusChem, 2019, 12 (3), pp.3008-3012. 10.1002/cssc.201900519 . hal-02087806

HAL Id: hal-02087806 https://hal-univ-rennes1.archives-ouvertes.fr/hal-02087806

Submitted on 18 Jul 2019

HAL is a multi-disciplinary open access archive for the deposit and dissemination of scientific research documents, whether they are published or not. The documents may come from teaching and research institutions in France or abroad, or from public or private research centers.
L'archive ouverte pluridisciplinaire HAL, est destinée au dépôt et à la diffusion de documents scientifiques de niveau recherche, publiés ou non, émanant des établissements d'enseignement et de recherche français ou étrangers, des laboratoires publics ou privés. 


\title{
Iron-Catalysed Reductive Amination of Carbonyl Derivatives with $\boldsymbol{\omega}$-Amino Fatty Acids to Access Cyclic Amines
}

\author{
Duo Wei[a], Chakkrit Netkaew ${ }^{[a]}$, Victor Carré ${ }^{[a]}$, and Christophe Darcel ${ }^{\star[a]}$ \\ Dedication ((optional))
}

\begin{abstract}
A new efficient method for the reductive amination of carbonyl derivatives with $\omega$-amino fatty acids catalysed by an iron complex $\mathrm{Fe}(\mathrm{CO})_{4}(\mathrm{IMes})$ by means of hydrosilylation was developed. A variety of pyrrolidines, piperidines and azepanes were selectively synthesised in moderate to excellent yields (36 examples, $47-97 \%$ isolated yields) with a good functional group tolerance.
\end{abstract}

The presence of $\mathrm{N}$-heterocycles is a characteristic feature in pharmaceutical chemistry, material chemistry, and synthetic organic chemistry. ${ }^{[1]}$ Particularly, cyclic amines (such as pyrrolidines, piperidines and azepanes) are present in a large class of natural products and biologically active molecules. ${ }^{[2]}$ (Figure 1)

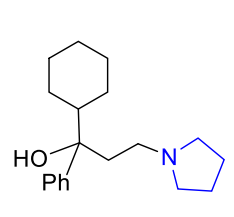

Procyclidine Anti-cholinergic drug Anti-melarial drug vasodilator and anti-sickling agent

Figure 1. Examples of cyclic amines in drug area

In the past few decades, huge efforts have been devoted to the development of efficient methods for the synthesis of cyclic amines, ${ }^{[3]}$ including hydrogen borrowing, ${ }^{[4]}$ ring-closing metathesis, ${ }^{[5]}$ reductive amination of keto acids (especially levulinic acid ${ }^{[6]}$ and intramolecular hydroamination reactions ${ }^{[7]}$ (Scheme 1a). In addition, those synthetic routes have been dominated by noble metals as the catalysts, for examples Ir, Ru, $\mathrm{Rh}$ and also $\mathrm{Pd}$. In comparison, Earth-abundant metals are relatively less applied in such transformations.

Recently, we have developed an iron-catalysed reductive amination of levulinic acid, 1,5- and 1,6-keto acids leading to pyrrolidines, piperidines and azepanes, respectively, under hydrosilylation conditions. ${ }^{[6]}$ From a sustainable organic synthesis point of view, iron-catalysed reductive amination of carbonyl derivatives with $\omega$-amino fatty acids should be another attractive method to access to $\mathrm{N}$-substituted cyclic amine

[a] D. Wei, C. Netkaew, V. Carré, Prof. Dr. C. Darcel Univ Rennes, CNRS, ISCR

(Institut des Sciences Chimiques de Rennes)

UMR 6226, F-35000, Rennes, France

E-mail: christophe.darcel@univ-rennes1.fr

Supporting information for this article is given via a link at the end of the document. derivatives in one step (Scheme $1 \mathrm{~b}$ ). Indeed, $\omega$-amino fatty acids are widely present in plants and animal species: as a representative example, 4-aminobutanoic acid (GABA) is the chief inhibitory neurotransmitter in the mammalian central nervous system and GABA is also sold as a dietary supplement. ${ }^{[8]}$ Furthermore, 5-aminopentanoic acid is a normal metabolite present in human saliva, with a tendency to elevated concentration in patients with chronic periodontitis, ${ }^{[9]}$ and 6aminohexanoic acid is effective in treatment of certain bleeding disorders (for instance postoperative bleeding), marketed as Amicar. ${ }^{[10]}$

a) Previous reported synthetic routes to $N$-substituted cyclic amines

$$
\begin{aligned}
& \mathrm{R}^{1}-\mathrm{NH}_{2}+\underset{\mathrm{HO}}{\sim} \mathrm{H}_{\mathrm{n}} x^{\mathrm{R}^{2}} \mathrm{OH} \underset{\text { additives }}{\text { cat. }} \stackrel{\mathrm{R}^{1}}{\sim} \underbrace{\mathrm{R}^{2}}_{\mathrm{n}}
\end{aligned}
$$

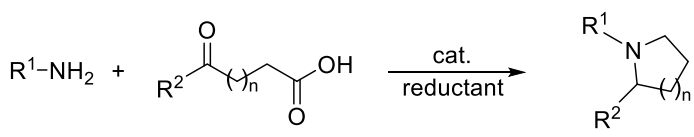

$$
\begin{aligned}
& \bigsqcup_{\mathrm{NHR}}{ }^{1} \text { or } \mathrm{R}^{2} \mathrm{NHR}_{\mathrm{n}}=\mathrm{R}^{2} \stackrel{\text { cat. }}{\longrightarrow} \mathrm{R}^{2} \text {, }
\end{aligned}
$$

b) Iron-catalysed reductive amination of carbonyl derivatives with $\omega$-amino fatty acids to access cyclic amines (this work)

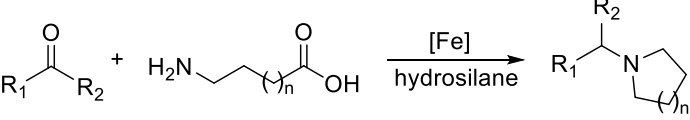

$$
[\mathrm{Fe}]=\mathrm{OCS}_{\mathrm{OO}}^{\mathrm{Mes}-\mathrm{Ne}}
$$

Scheme 1. a) Representative synthetic routes to $\mathrm{N}$-substituted cyclic amines and b) Iron-catalysed reductive amination of carbonyl derivatives with $\omega$-amino fatty acids (this work).

On the other hand, the last two decades have seen an impressive improvement of the use of iron as a fascinating and valuable alternative transition metal in homogeneous catalysis, more particularly in the reduction areas. ${ }^{[11]}$ For the synthesis of amines, reductive amination is one of most efficient methodologies ${ }^{[12]}$ in particular with iron catalysts which exhibited good activities. ${ }^{[13]}$ Additionally, reduction via hydrosilylation is a promising alternative for the selective catalytic transformation of organic molecules compared to other reduction methods such as the catalytic hydrogenation ${ }^{[14]}$ and transfer hydrogenation reactions, ${ }^{[15]}$ or the stoichiometric reduction with metal hydrides 
(e.g. aluminium and boron hydrides). ${ }^{[16]}$ Thus the use of hydrosilanes is often interesting owing to its operational simplicity, mild conditions and excellent chemoselectivity. ${ }^{[17]}$ Therefore hydrosilanes can be considered as interesting alternative reductants, although siloxane waste is an unavoidable by-product during those procedures.

Among the different well-defined iron complexes developed in our group for reduction reactions, $\mathrm{Fe}(\mathrm{CO})_{4}(\mathrm{IMes}) \mathbf{A}[\mathrm{IMes}=1,3$ bis (2,4,6-trimethylphenyl)imidazol-2-ylidene, Scheme 1b] was efficiently employed as catalyst in the hydrosilylation of esters ${ }^{[18]}$, hydroboration of alkenes ${ }^{[19]}$ and methylation of secondary amines. ${ }^{[20]}$, Additionally, Royo also described for the hydrosilylation of benzaldehyde derivatives using $\mathbf{A}$ as the catalyst, and Mandal using an abnormal-NHC-Fe(CO) $)_{4}$ succeeded to performed the hydrosilylation of imines with high efficiency. ${ }^{[21]}$

Herein, we report an iron-catalysed efficient and selective one-pot preparation of $\mathrm{N}$-substituted cyclic amines (including pyrrolidines, piperidines and azepanes) via reductive amination of carbonyl derivatives with $\omega$-amino fatty acids by hydrosilylation (Scheme 1b).

Inspired by recent reports on the preparation of cyclic amines ${ }^{[6]}$ and the application of $\mathrm{Fe}(\mathrm{CO})_{4}(\mathrm{IMes}) \mathbf{A}$ in reduction area, ${ }^{[20-21]}$ we began our initial optimization work with benzaldehyde 1a, 5-aminopentanoic acid 2 and phenylsilane in toluene, in the presence of $\mathbf{A}$ as the catalyst. The preliminary experiment using $5 \mathrm{~mol} \%$ of $\mathbf{A}$ associated to 4 equiv. of $\mathrm{PhSiH}_{3}$ at $100{ }^{\circ} \mathrm{C}$ upon visible light irradiation (using 24 watt compact fluorescent lamp) showed an interesting result for reductive amination of $\mathbf{1 a}$ and 2: thus, $N$-benzylpiperidine $3 \mathbf{a}$ was produced in $96 \%$ yield (Table 1 , entry 1 ) with only $3 \%$ of benzyl alcohol 5 resulting of the reduction of the benzaldehyde, indicating the remarkable selectivity with respect to $\mathbf{3 a}$.

Afterwards, different hydrosilanes were evaluated in order to study the selectivity of the reaction. Using diphenylsilane (6 equiv.) led to a mixture of 1-benzylpiperidin-2-one $(4,59 \%)$ and benzyl alcohol $(5,40 \%$ with no trace amount of the expected piperidine 3a, entry 2), while with TMDS (1,1,3,3- tetramethyldisiloxane, 6 equiv.) and PMHS (polymethylhydrosiloxane, 12 equiv.) no reaction occurred (entries 3 and 4). The absence of toluene or visible light irradiation resulted in deteriorative selectivity (entries 5 and 6 ) as $3 a$ was obtained in mixture with 4 . Decreasing the temperature to 80 or $50{ }^{\circ} \mathrm{C}$ led to a mixture of $3 \mathrm{a}$ and 4 with an increasing amount of $4(50 \%$ and $65 \%$, respectively, entries 7 and 8 ). Nevertheless, when the reaction was conducted at $30{ }^{\circ} \mathrm{C}$, the conversion was $96 \%$ with benzyl alcohol $\mathbf{5}$ as the major product $(64 \%$, entry 9$)$. The quantity of hydrosilanes has also a crucial effect on the selectivity; indeed, increasing the amount of phenylsilane to 5 equiv. or decreasing to 3 and 2 equiv. lowered the selectivity of the reaction (entries 10-12 vs 1). Finally, with a lower catalyst loading of $\mathbf{A}(2.5 \mathrm{~mol} \%)$, a lower conversion $(86 \%)$ was obtained, with $\mathbf{3 a}$ still being the major product $(71 \%$, entry 13). Noticeably, in the absence of catalyst $\mathbf{A}$ under similar conditions with 2-4 equiv. of phenylsilane, no $\mathrm{N}$-benzylpiperidine 3a was obtained; the main product obtained was the $\mathrm{N}$ benzylpiperidinone 4. Additionally, using $\mathrm{Fe}(\mathrm{CO})_{5}$ or $\mathrm{Fe}_{3}(\mathrm{CO})_{12}$ under our optimized conditions, even if full conversions were observed, benzyl alcohol resulting from the reduction of benzaldehyde was the major product obtained (59 and 99\% respectively), showing the crucial role of the IMes ligand for the selectivity of the reaction. It must be also mentioned that this transformation using the catalyst $\mathbf{A}$ under hydrogenation or hydrogen transfer conditions did not succeed (Table S2).

Table 1. Optimization of the reaction parameters. ${ }^{[a]}$

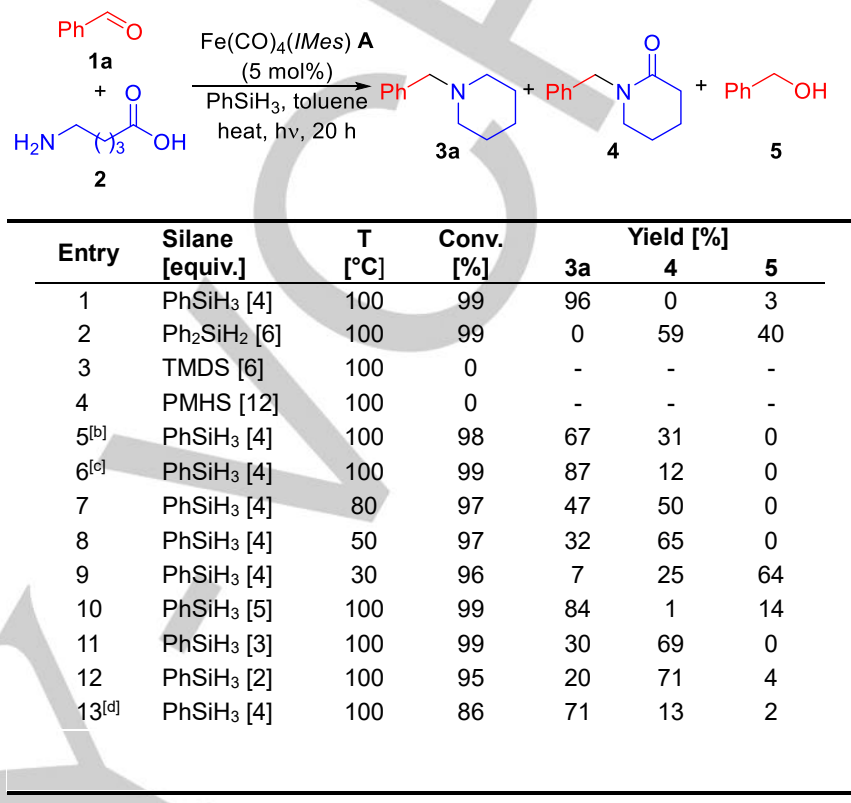

[a] General reaction conditions: A $(5 \mathrm{~mol} \%), 2(0.5 \mathrm{mmol}), \mathbf{1 a}(0.5 \mathrm{mmol})$, $\mathrm{PhSiH}_{3}$ and toluene $(0.5 \mathrm{~mL})$, visible light irradiation (using 24 watt compact fluorescent lamp), $100^{\circ} \mathrm{C}, 20 \mathrm{~h}$; then hydrolysis (THF/NaOH $2 \mathrm{~N}$ ). The conversions and yields were determined by ${ }^{1} \mathrm{H}$ NMR spectroscopy. [b] neat condition. [c] In the absence of visible light irradiation. [d] A (2.5 mol\%).

With our optimized conditions in hand $(5 \mathrm{~mol} \%$ of $\mathbf{A}, 4$ equiv. of $\mathrm{PhSiH}_{3}$, toluene, $100{ }^{\circ} \mathrm{C}, 20 \mathrm{~h}$, visible light irradiation, Table 1 , entry 1), we then explored the substrate scope for the catalysed reductive amination of carbonyl derivatives with $\omega$-amino fatty acids into $\mathrm{N}$-substituted cyclic amines (Tables 2, 3 and 4). Benzaldehyde, 0 - and $p$-tolualdehyde were smoothly converted into the corresponding $N$-substituted piperidines in $92-95 \%$ isolated yields (3a-3c, Table 2). Starting from the hindered mesitaldehyde, the corresponding product $\mathbf{3} \mathbf{d}$ was isolated in good yield $(80 \%)$. The reactions of $p$-methoxy or $p-N, N$-dimethyl benzaldehyde afforded the corresponding piperidines $3 e-3 f$ in 93 and $63 \%$ yields, respectively.

The reaction also tolerated halides giving $\mathbf{3 g}-\mathbf{3} \mathbf{i}$ in $93-95 \%$ yields. Notably, piperidines bearing reducible functional groups such as carboxylic ester $(\mathbf{3} \mathbf{j})$ and amide (3k), were prepared in 62 and $78 \%$ yields, respectively highlighting the good group tolerance of this transformation. The reaction with $p$ (acetyl)aniline led to a less selective reaction as $72 \%$ of the piperidine 3 I was obtained in mixture with $20 \%$ of the fully reduced product, 1-((p-piperidylmethyl)phenyl)ethan-1-ol. Additionally, hetero-aromatic aldehydes based on pyrrole, furan, thiophene and quinoline cores were effectively transformed to $3 m-3 p$ in yields up to $97 \%$. Ferrocene substituent was also tolerated as $\mathbf{3 q}$ was isolated in $89 \%$. Interestingly, starting from isophthalaldehyde, the corresponding dipiperidine derivative $3 r$ 
can be purified in moderated yield $\quad(58 \%)$. When $\alpha, \beta$-unsaturated aldehyde such as cinnamaldehyde was used, $N$ cinnamylpiperidine 3s was obtained in $73 \%$ isolated yield. Furthermore, linear aldehyde such as 10 -undecenal reacted selectively leading to the piperidine $3 \mathrm{t}$ in $96 \%$ yield without hydrosilylation of the terminal $\mathrm{C}=\mathrm{C}$ bond, exhibiting the good functional tolerance towards conjugated or remoted $\mathrm{C}=\mathrm{C}$ bonds. Noticeably, the reaction can be also conducted with acetophenone, although moderate yield was achieved (3u, $56 \%$ ).

Table 2. Scope of the synthesis of piperidines by reductive amination of carbonyl derivatives with 5-aminopentanoic acid. ${ }^{\text {[a] }}$

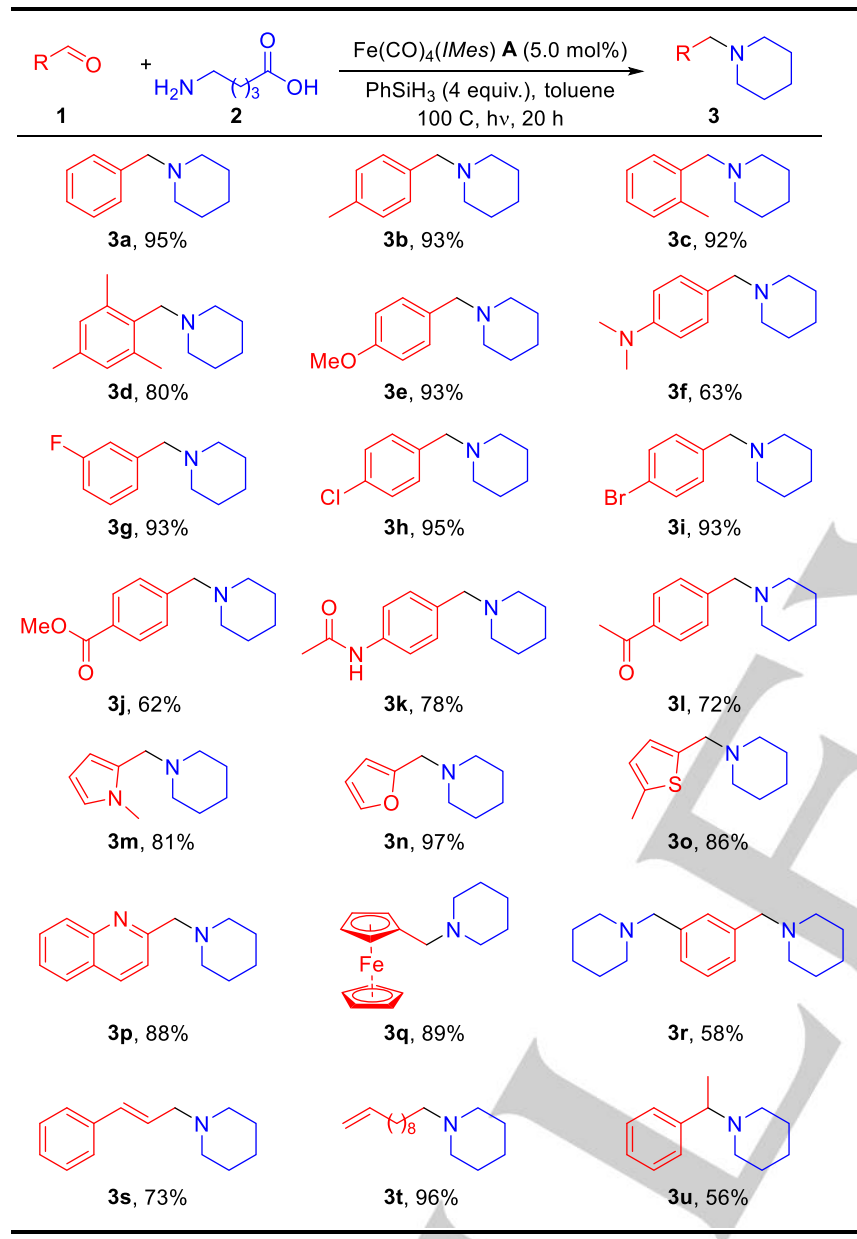

[a] General reaction conditions: A (5 mol\%), $2(0.5 \mathrm{mmol}), \mathbf{1}(0.5 \mathrm{mmol})$ $\mathrm{PhSiH}_{3}$ (4 equiv.) and toluene $(0.5 \mathrm{~mL})$, visible light irradiation, $100^{\circ} \mathrm{C}, 20 \mathrm{~h}$; then hydrolysis ( $\mathrm{THF} / \mathrm{NaOH} 2 \mathrm{~N}$ ). Isolated yields of $\mathbf{3}$ are shown.

Next, the reductive amination of carbonyl derivatives reaction was extended to 6 -aminohexanoic acid $\mathbf{6}$, in order to synthesise azepanes (Table 3 ). In the selected examples depicted in Table $3, p$-chloro and $p$-methoxy substituted benzaldehydes afforded the corresponding azepanes in $95 \%$ and $90 \%$ yields, respectively. The steric hindrance did not inhibit the transformation as the product $7 \mathrm{c}$ derived from mesitaldehyde can be isolated in $75 \%$ yield. Cyano reducible functional group was tolerated and $\mathbf{7 d}$ was isolated in $82 \%$ yield. Heteroaromatic aldehydes based on quinoline, thiophene and furan cores were effectively transformed to $\mathbf{7 e - 7 g}$ in yields up to $95 \%$. Remoted $\mathrm{C}=\mathrm{C}$ group was not hydrosilylated and $7 \mathrm{~h}$ was isolated in $94 \%$ yield. Ketones are also appropriate partners in the preparation of azepanes. Indeed, cyclohexanone and acetophenone led to the corresponding azepanes $7 \mathbf{i}$ and $7 \mathbf{j}$ in $87 \%$ and $47 \%$ yields.

Table 3. Scope of the synthesis of azepanes by reductive amination of carbonyl derivatives with 6 -aminohexanoic acid. ${ }^{[a]}$

substrate 1
Entry
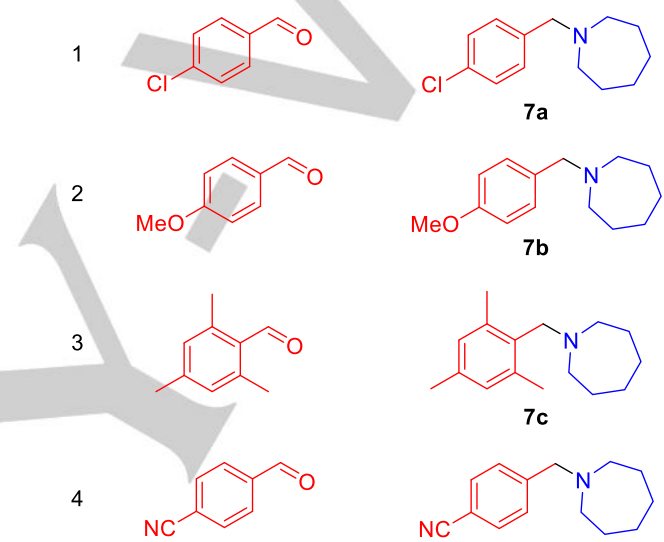<smiles>COc1ccc(CN2CCCCCC2)cc1</smiles>

$7 \mathrm{~b}$<smiles>Cc1cc(C)c(CN2CCCCCC2)c(C)c1</smiles>

7c<smiles>N#Cc1ccc(CN2CCCCCC2)cc1</smiles>
82

$7 d$<smiles>O=Cc1ccc2ccccc2n1</smiles><smiles>c1ccc2nc(CN3CCCCCC3)ccc2c1</smiles>
91 $7 e$<smiles>Cc1ccc(CN2CCCCCC2)s1</smiles>

$7 f$<smiles>C=CCC(=O)O</smiles><smiles>c1coc(CN2CCCCCC2)c1</smiles>
$7 \mathrm{~g}$<smiles>C=CCN1CCCCCC1</smiles>
$7 \mathrm{~h}$<smiles>O=C1CCCCC1</smiles><smiles>CC(=O)c1ccccc1</smiles><smiles>CC(c1ccccc1)N1CCCCCC1</smiles>

47

[a] General reaction conditions: A $(5 \mathrm{~mol} \%), 6(0.5 \mathrm{mmol}), 1(0.5 \mathrm{mmol})$ $\mathrm{PhSiH}_{3}$ (4 equiv.) and toluene $(0.5 \mathrm{~mL})$, visible light irradiation, $100{ }^{\circ} \mathrm{C}, 20 \mathrm{~h}$; then hydrolysis $(\mathrm{THF} / \mathrm{NaOH} 2 \mathrm{~N})$. Isolated yields of 7 are shown. 
Finally, to show the generality of this cyclic amine preparation, 4-aminobutanoic acid (8, GABA) was employed with different aldehydes to prepare pyrrolidines 9 as shown in Table 4 . Thus, $p$ fluorobenzaldehyde furnished $9 a$ in $93 \%$ yield. Heteroaromatic aldehydes containing quinoline, thiophene and furan groups can be effectively transformed to $9 \mathbf{b}-\mathbf{9 d}$ in good yields (87-90\%). Similar to piperidine $3 \mathbf{t}$ and azepane $\mathbf{7 h}$, pyrrolidine $9 \mathrm{e}$ was prepared in $95 \%$ yield starting from 10-undecenal and 8 , again without alteration of the $\mathrm{C}=\mathrm{C}$ bond. Even though this method is quite general for the synthesis of 5,6 and 7 membered cyclic amines, the reaction of $\beta$-alanine with benzaldehyde did not furnish the desired azetidine product, but the $3-(N-$ benzylamino)propanoic acid was the sole product obtained with $83 \%$ NMR yield. (see supporting information, Scheme S3).

Table 4. Scope of the synthesis of pyrrolidines by reductive amination of aldehydes with 4-aminobutanoic acid. ${ }^{\text {[a] }}$

substrate 1

[a] General reaction conditions: $\mathbf{A}(5 \mathrm{~mol} \%), 8(0.5 \mathrm{mmol}), \mathbf{1}(0.5 \mathrm{mmol})$ $\mathrm{PhSiH}_{3}$ (4 equiv.) and toluene $(0.5 \mathrm{~mL})$, visible light irradiation, $100^{\circ} \mathrm{C}, 20 \mathrm{~h}$; then hydrolysis (THF/NaOH $2 \mathrm{~N}$ ). Isolated yields of 9 are shown.

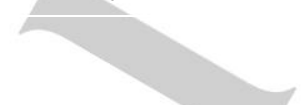

Summarising the results described above, cyclic amines can be formed efficiently by the iron catalysed hydrosilylation of $\omega$ amino fatty acids in the presence of aldehydes. Importantly, it was shown that the first steps of the transformation generating specifically piperidinone 4 (i.e. imine formation, its reduction then transamidation) can be performed in the absence of iron catalyst (see table S1). This transformation seems to be specific to $\omega$ amino fatty acids used as with methyl 4-aminobutyric ester, no reduction reaction occurred. Noticeably, carboxylic acids seem to promote the formation of imines in the presence of hydrosilanes (Schemes S2). ${ }^{[22-24]}$ Additionally, the reduction of piperidinones with phenylsilane can be performed only in the presence of iron catalyst.

On another hand, to have information on the nature of the iron active species, a reductive amination of 1 a with 2 using $5 \mathrm{~mol} \%$ of $\mathbf{A}$ in the presence of 4 equiv. of $\mathrm{PhSiH}_{3}$ was conducted in a Young NMR tube with visible light irradiation. Noticeably, the signal of $\mathrm{H}_{2}$ and $\mathrm{Fe}-\mathrm{H}$ species were observed at $4.46 \mathrm{ppm}$ and $9.13 \mathrm{ppm}$, respectively, after $3 \mathrm{~h}$ of reaction at $100{ }^{\circ} \mathrm{C}$ (Figure S1 and S2). The Fe-H signal is very close to the one observed in hydrosilylation of esters. ${ }^{[18]}$

Based on these observations and on the previous reaction proposed pathways, ${ }^{[2 c, 6]}$ an imine intermediate $\mathbf{l}-\mathbf{1}$ is first produced by condensation of $\mathbf{1 a}$ with $\mathbf{2}$ and dehydrogenative silylation of the carboxylic acid moiety with phenylsilane, then generating $\mathrm{H}_{2}$. The reduction of the imine moiety of $\mathbf{l}-\mathbf{1}$ under hydrosilylation conditions generated the silylamine intermediate $\mathbf{~ - 2}$, then the piperidinone 4 via intramolecular transamidation (Scheme 2). The final step is an iron-catalyzed reduction of $\mathbf{4}$ into $\mathbf{3 a}$ under hydrosilylation conditions. ${ }^{[18,25]}$

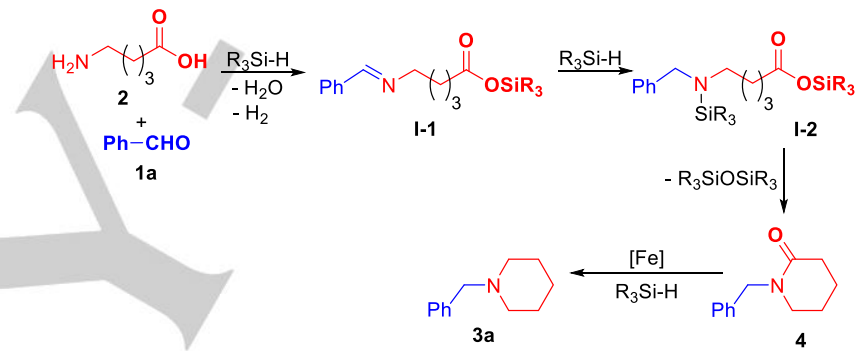

Scheme 2. Possible reaction pathway.

In summary, this contribution described an unprecedented efficient method for the preparation of $\mathrm{N}$-substituted cyclic amines (including pyrrolidines, piperidines and azepanes) starting from $\omega$-amino fatty acids and a variety of carbonyl derivatives, via reductive amination. The reaction proceeds with a high functional group tolerance as reducible groups such as carboxylic ester, amide, cyano and even acetyl, are well tolerated. The notable features of this protocol include the use of an Earth-abundant, nontoxic metal iron complex bearing a $\mathrm{N}$-heterocyclic carbene ( $\mathrm{NHC})$ ligand as the catalyst $(5 \mathrm{~mol} \%)$ in the presence of phenylsilane (4 equiv.) as the reducing agent at $100^{\circ} \mathrm{C}$ and visible-light activation of the catalyst.

\section{Experimental Section}

Typical procedure for catalytic reductive amination of carbonyl derivatives with $\omega$-amino fatty acids

A $20 \mathrm{~mL}$ Schlenk tube was charged with $\left[\mathrm{Fe}(\mathrm{CO})_{4}(\mathrm{IMes})\right]$ A $(5 \mathrm{~mol} \%), \omega-$ amino fatty acids 2,6 or $8(0.5 \mathrm{mmol})$, aldehyde $\mathbf{1}(0.5 \mathrm{mmol}), \mathrm{PhSiH}_{3}$ (4 equiv.) and toluene $(0.5 \mathrm{~mL}$ ) under the argon atmosphere in this order. Then the reaction mixture was stirred upon visible light irradiation (using 24 watt compact fluorescent lamp) at $100^{\circ} \mathrm{C}$ for $20 \mathrm{~h}$. After cooling to room temperature, the reaction was quenched by adding $2 \mathrm{~mL}$ THF and $2 \mathrm{~mL}$ $\mathrm{NaOH}$ (aq.) $2 \mathrm{~N}$, stirred for $2 \mathrm{~h}$ at room temperature and then extracted 
with $3 \times 2 \mathrm{~mL}$ of ethyl acetate. The combined organic fractions were dried over anhydrous $\mathrm{Na}_{2} \mathrm{SO}_{4}$ for $0.5 \mathrm{~h}$. After filtrate through degreasing cotton, the crude mixture was dried under reduced pressure. The residue was then purified by silica gel column chromatography using a mixture of heptane/ethyl acetate $(60: 1$ to $5: 1)$ as the eluent to afford the desired product.

\section{Acknowledgements}

We thank the Universite de Rennes 1 and the Centre National de la Recherche Scientifique (CNRS). C. N. thanks French Embassy in Thailand for a grant.

\section{Conflict of interest}

\section{The authors declare no conflict of interest}

Keywords: iron catalysis $\cdot$ reductive amination $\bullet \omega$-amino fatty acids $\bullet$ cyclic amines $\bullet$ hydrosilylation

[1] a) C. W. Bird, Comprehensive Heterocyclic Chemistry II, Pergamon Oxford, 1996; b) J. A. Joule, K. Mills, Heterocyclic Chemistry, 5th ed. Wiley-Blackwell, Chichester, 2010.

[2] a) D. O'Hagan, Nat. Prod. Rep. 1997, 14, 637-651; b) D. O'Hagan, Nat. Prod. Rep. 2000, 17, 435-446.

[3] I. Nakamura, Y. Yamamoto, Chem. Rev. 2004, 104, 2127-2198.

[4] For representative examples, see: a) Y. Tsuji, K. T. Huh, Y. Ohsugi, Y. Watanabe, J. Org. Chem. 1985, 50, 1365-1370; b) K.-i. Fujita, T. Fujii, R. Yamaguchi, Org. Lett. 2004, 6, 3525-3528; c) D. Hollmann, S. Bähn, A. Tillack, R. Parton, R. Altink, M. Beller, Tetrahedron Lett. 2008, 49, 5742 5745; d) K. Yuan, F. Jiang, Z. Sahli, M. Achard, T. Roisnel, C. Bruneau, Angew. Chem. Int. Ed. 2012, 51, 8876-8880; Angew. Chem. 2012, 124 9006-9010.

For representative review, see: e) M. H. S. A. Hamid, P. A. Slatford, J. M J. Williams, Adv. Synth. Catal. 2007, 349, 1555-1575; f) A. Corma, J Navas, M. J. Sabater, Chem. Rev. 2018, 118, 1410-1459; g) T. Irrgang R. Kempe, Chem.Rev. 2019, 10.1021/acs.chemrev.8b00306

[5] For a representative review, see: F.-X. Felpin, J. Lebreton, Eur. J. Org. Chem. 2003, 3693-3712.

[6] a) Y. Ogiwara, T. Uchiyama, N. Sakai, Angew. Chem. Int. Ed. 2016, 55 1864-1867; Angew. Chem. 2016, 128, 1896-1899; b) C. Wu, X. Luo, H. Zhang, X. Liu, G. Ji, Z. Liu, Z. Liu, Green Chem. 2017, 19, 3525-3529; c) D. Wei, C. Netkaew, C. Darcel, Adv. Synth. Catal. 2019, do 10.1002/adsc. 201801656 .

[7] For a representative review, see: a) T. E. Müller, M. Beller, Chem. Rev. 1998, 98, 675-704; using iron as catalysts, see: b) S. Bezzenine-Lafollée R. Gil, D. Prim, J. Hannedouche, Molecules 2017, 22, 1901; c) C. Lepori, J. Hannedouche, Synthesis 2017, 49, 1158-1167.

[8] M. Watanabe, K. Maemura, K. Kanbara, T. Tamayama, H. Hayasaki, in International Review of Cytology, Vol. 213 (Ed.: K. W. Jeon), Academic Press, 2002, pp. 1-47.

[9] S. Syrjänen, P. Piironen, H. Markkanen, Arch. Oral. Biol. 1987, 32, 607 610.

[10] a) N. Alkjaersig, A. P. Fletcher, S. Sherry, J. Biol. Chem. 1959, 234, 832; b) J. Lu, H. Meng, Z. Meng, Y. Sun, J. P. Pribis, C. Zhu, Q. Li, Int. J. Clin. Exp. Pathol. 2015, 8, 7978-7987.

[11] For selected reviews, see: a) C. Bolm, J. Legros, J. Le Paih, L. Zani, Chem. Rev. 2004, 104, 6217-6254; b) B. Plietker, Iron catalysis in organic chemistry: reactions and applications, Wiley- $\mathrm{VCH}$, Weinheim 2008; c) R. H. Morris, Chem. Soc. Rev. 2009, 38, 2282-2291; d) C.-L. Sun, B.-J. Li, Z.-J. Shi, Chem. Rev. 2010, 111, 1293-1314; e) K. Junge, K. Schröder, M. Beller, Chem. Commun. 2011, 47, 4849-4859; f) B. A. F. Le Bailly, S. P. Thomas, RSC Adv. 2011, 1, 1435-1445; g) C. Darcel, J.B. Sortais, in Iron Catalysis II, Vol. 50 (Ed.: E. Bauer), Springer, 2015, pp. 173-216; h) I. Bauer, H.-J. Knölker, Chem. Rev. 2015, 115, 3170-3387; i) N. Guo, S. F. Zhu, Chin. J. Org. Chem. 2015, 35, 1383-1398; j) R Lopes, B. Royo, Isr. J. Chem. 2017, 57, 1151-1159; k) D. Wei, C. Darcel, Chem. Rev. 2019, DOI: 10.1021/acs.chemrev.8b00372.

[12] For a review, see: a) T. C. Nugent, M. El-Shazly, Adv. Synth. Catal. 2010 352, 753-819; for selected exemples of recent catalyzed reductive amination, see: b) R. V. Jagadeesh, K. Murugesan, A. S. Alshammari, H.
Neumann, M.-M. Pohl, J. Radnik, M. Beller, Science 2017, 358, 326-332; c) T. Senthamarai, K. Murugesan, J. Schneidewind, N. V. Kalevaru, W. Baumann, H. Neumann, P. C. J. Kamer, M. Beller, R. V. Jagadeesh Nature Commun. 2018, 9, 4123; d) T. Senthamarai, K. Murugesan, K Natte, N. V. Kalevaru, H. Neumann, P. C. J. Kamer, R. V. Jagadeesh, ChemCatChem, 2018, 10, 1235-1240; e) G. Hahn, P. Kunnas, N. de Jonge, R. Kempe, Nature Catal., 2019, 2, 71.

[13] At iron, examples of DRA under hydrogenation conditions, see: a) M. D. Bhor, M. J. Bhanushali, N. S. Nandurkar, B. M. Bhanage, Tetrahedron Lett. 2008, 49, 965-969; b) S. Fleischer, S. Zhou, K. Junge, M. Beller Chem. Asian J. 2011, 6, 2240-2245; c) A. Pagnoux-Ozherelyeva, N. Pannetier, M. D. Mbaye, S. Gaillard, J.-L. Renaud, Angew. Chem. Int Ed. 2012, 51, 4976-4980; d) S. Moulin, H. Dentel, A. PagnouxOzherelyeva, S. Gaillard, A. Poater, L. Cavallo, J. F. Lohier, J. L. Renaud, Chem. Eur. J. 2013, 19, 17881-17890; e) S. Zhou, S. Fleischer, H. Jiao, K. Junge, M. Beller, Adv. Synth. Catal. 2014, 356, 3451-3455; for examples of DRA under hydrogen transfer conditions, see: $f) M$. Bala, P. K. Verma, U. Sharma, N. Kumar, B. Singh, Green Chem. 2013, 15, 1687 1693; for examples of DRA under hydrogen b orrowing conditions, see: g) T. Yan, B. L. Feringa, K. Barta, Nat. Commun. 2014, 5, 5602; h) T. Yan, B. L. Feringa, K. Barta, ACS Catal. 2016, 6, 381-388; i) B. Emayavaramban, M. Roy, B. Sundararaju, Chem. Eur. J. 2016, 22, 3952 3955; j) A. J. Rawlings, L. J. Diorazio, M. Wills, Org. Lett. 2015, 17, 10861089; k) T. J. Brown, M. Cumbes, L. J. Diorazio, G. J. Clarkson, M. Wills, J. Org. Chem. 2017, 82, 10489-10503; I) H.-J. Pan, T. W. Ng, Y. Zhao, Chem. Commun. 2015, 51, 11907-11910; m) T. Yan, B. L. Feringa, K Barta, Sci. Adv. 2017, 3, eaao6494; n) A. Lator, S. Gaillard, A. Poater J.-L. Renaud, Org. Lett. 2018, 20, 5985-5990; o) K. Polidano, B. D. W. Allen, J. M. J. Williams, L. C. Morrill, ACS Catal. 2018, 8, 6440-6445; p) B. Emayavaramban, M. Sen, B. Sundararaju, Org. Lett. 2016, 19, 6-9; q) T. Yan, K. Barta, 2016, 9, 2321-2325; r) M. Pena-Lopez, H. Neumann, M. Beller, ChemCatChem 2015, 7, 865-871; s) M. Mastalir, M. Glatz, N. Gorgas, B. Stöger, E. Pittenauer,G. Allmaier, L. F. Veiros, K. Kirchner, Chem.-Eur. J. 2016, 22, 12316-12320; for examples of DRA under hydrosilylation conditions, see: t) S. Enthaler, ChemCatChem 2010, 2, 1411-1415; u) H. Jaafar, H. Li, L. C. Misal Castro, J. Zheng, T. Roisnel, V. Dorcet, J.-B. Sortais, C. Darcel, Eur. J. Inorg. Chem. 2012, 3546-3550

[14] J. G. d. Vries, C. J. Elsevier, The handbook of homogeneous hydrogenation, Wiley-Vch, Weinhem, 2007

[15] a) G. Brieger, T. J. Nestrick, Chem. Rev. 1974, 74, 567-580; b) R. Noyori, S. Hashiguchi, Acc. Chem. Res. 1997, 30, 97-102.

[16] G. W. Gribble, Chem. Soc. Rev. 1998, 27, 395-404.

[17] M. Zhang, A. Zhang, Appl. Organomet. Chem. 2010, 24, 751-757.

[18] a) H. Li, L. C. Misal Castro, J. Zheng, T. Roisnel, V. Dorcet, J.-B. Sortais, C. Darcel, Angew. Chem. Int. Ed. 2013, 52, 8045-8049; Angew. Chem. 2013, 125, 8203-8207; b) S. Quintero-Duque, H. Li, L. C. Misal Castro, V. Dorcet, T. Roisnel, E. Clot, M. Grellier, J.-B. Sortais, C. Darcel, Isr. J. Chem. 2017, 57, 1216-1221.

[19] J. Zheng, J.-B. Sortais, C. Darcel, ChemCatChem 2014, 6, 763-766.

[20] J. Zheng, C. Darcel, J.-B. Sortais, Chem. Commun. 2014, 50, 1422914232.

[21] a) S. Warratz, L. Postigo, B. Royo, Organometallics 2013, 32, 893-897 b) M. Bhunia, P. K. Hota, G. Vijaykumar, D. Adhikari, S. K. Mandal, Organometallics 2016, 35, 2930-2937.

[22] Noticeably, the reaction of $p$-methoxybenzylidenebenzimide with 2 equiv. of phenylsilane in toluene at $100{ }^{\circ} \mathrm{C}$ for $4 \mathrm{~h}$ led to only $14 \%$ of $(p$ methoxybenzylphenylamine. The same reaction in the presence of 1 equiv. of acetic acid led to $51 \%$ of the resulting amine. (see Scheme S1)

[23] The reductive amination reaction of benzaldehyde with butylamine in the presence of 2 equiv. of phenylsilane and 1 equiv. of carboxylic acid (acetic or valeric) led to the imine as the major product $(70-75 \%$ yields) with dibenzylbutylamine and $\mathrm{N}$-benzyl-N-butylcarbamides as the byproducts whereas without carboxylic acid, only the imine was obtained. (see scheme S2)

[24] a) Y. Li, J. A. Molina de La Torre, K. Grabow, U. Bentrup, K. Junge, S Zhou, A. Brückner, M. Beller, Angew. Chem. Int. Ed. 2013, 52, 11577 11580; Angew. Chem. 2013, 125, 11791 - 11794; b) M. P. Doyle, D. J. DeBruyn, D. A Kooistra, J. Am. Chem. Soc. 1972 94, 3659-3661; c) X Chen, Y. Deng, K. Jiang, G. Lai, Y. Ni, K. Yang, J. Jiang, L. Xu, Eur. J. Org. Chem. 2011, 1736, d) Y. Li, L.-Q. Lu, S. Das, S. Pisiewicz, K. Junge, M. Beller, J. Am. Chem. Soc. 2012, 134, 18325.

[25] a) S. Zhou, K Junge, D. Addis, S. Das, M. Beller, Angew. Chem. 2009, 121, 9671-9674; Angew. Chem. Int. Ed. 2009, 48, 95079510; b) Y. Sunada, H. Kawakami, T. Imaoka, Y. Motoyama, H. Nagashima, Angew. Chem. 2009, 121, 9675-9678; Angew. Chem. Int Ed. 2009, 48, 9511-9514; c) D. Bézier, G. T. Venkanna, J.-B. Sortais, C. Darcel, Chem CatChem 2011, 3, 1747: d) S. Das, B. Wendt, K. Möller, K. Junge, M. Beller, Angew. Chem. 2012, 124, 1694-1698; Angew. Chem. Int. Ed. 2012, 51, 1662-1666. 
Entry for the Table of Contents (Please choose one layout)

\section{COMMUNICATION}

$$
\begin{gathered}
\mathrm{P}_{\mathrm{h}, 20 \mathrm{~h}} \\
\mathrm{R}_{2}
\end{gathered}
$$

An unprecedented efficient method for the reductive amination of carbonyl derivatives with $\omega$-amino fatty acids catalysed by an iron complex was developed. A variety of pyrrolidines, piperidines, azepanes were synthesised in $47-97 \%$ isolated yields (36 examples).
Duo Wei, Chakkrit Netkaew, Victor Carré, and Christophe Darcel*

Page No. - Page No.

Iron-Catalysed Reductive Amination of Carbonyl Derivatives with $\omega$-Amino Fatty Acids to Access Cyclic Amines 